SB 981

. 95

1917

Copy 1 


\section{THE PLANT QUARANTINE ACT, AUGUST 20, 1912, AS AMENDED MARCH 4, 1913, AND MARCH 4, 1917.}

AN ACr To regulate the importation of nursery stock and other plants and plant products: to enable the Seeretary of Agriculture to establish and maintain quarantine districts for plant diseases and insect pests; to permit and regulate the moventent of fruits, plants, and regetables therefrom, and for other purposes.

Be it encted by the Scuntc and House of Representalices of the United States of America in Congress assembted, That it shall be mulawful for any person to import or offer for entry into the United States iny nursery stock unless and until a permit shall bave been issued therefor by the Secretary of Agriculture, under sucli conditions and regulations as the said Secretary of Agriculture may prescribe, and unless such nursely stock shall be accompanied by a certificate of inspection, in mamner and form as required by the Secretary of Agriculture, of the proper official of the country from which the importation is made, to the effect that the stock has been thoroughly inspected and is believed to be free from injurious plant diseases and insect pests: Provided, 'That the Secretary of Agriculture shall issue the permit for any particular importation of nursery stock when the conditions and regulations as prescribed in this act shall have been complied with: Prorided further, 'That nursery stock may be imported for experimental or scientific purposes by the Department of Agriculture upon such conditions and under such regulitions as the said Secretary of Agriculture may prescribe: And provided further, That nursery stock imported from countries where no ofticial system of inspection for such stock is maintained may be admitted upon such conditions and under such legulations as the Secretary of Agriculture may prescribe.

SEC. 2. That it slall be the duty of the Secretaly of the Treasury promptly to notify the Secretary of Agriculture of the arrival of any nursery stack at port of entry; that the person receiving such stock at port of entry shall, immediately upon entry and before such stock is delivered for shipment or removed from the port of entry, advise the Secretary of Agriculture or, at his direction, the proper State, Territorial, or District oflicial of the State or 'Terlitory or the District to which such nulsery stock is destined, or botll, as the Secretary of Agriculture may elect, of the name and address of the consignee, the nature and quantity of the stock it is proposed to ship, and the country and locality where the same was glown. That no person shall ship or offer for shipinent from one State or Territory or District of the United States into any other State or Territory or District, any nursery stock imported into the United States without notifying the Secretary of Agriculture or, at his direction, the proper State, Territorial, or District oflicial of the State or Territory or District to which such nursery stock is destined, or both, as the Secretary of Agriculture may elect, immediately upon the delivery of the said stock for shipment, of the name and address of the consignee, of the nature and quantity of stock it is proposed to ship, and the country and locality where the same was grown, unless and until such imported stock has been inspected by the proper official of a State, Territory, or District of the United States.

SEc. 3. That no person shall import or offer for entry into the United States any nursery stock unless the case, box. I)ackage, crate, bale, or bundle theleof shall be plainly and correcty marked to show the general nature and quantity of the contents, the country and locality where the same was grown, the name and address of the shipper, owner, or person shipping or forwarding the same, and the name and address of the consignee.

SEc. 4. That no person shall ship or deliver for shipment from one State or Territory or District of the United States into any other State or Territory or District any such imported nursery stock the case, box, package, crate, bale, or bundle whereof is not plainly marked so as to show the general nature and quantity of the contents, the name and address of the consignee, and the country and locality where such stock was grown, unless and until such imported stock 
has been inswerterl by the proper oflicial of a state, 'Territory, or District of the Uniterl States.

SEc. 5. That whenever the Secretary of Agriculture slatl retermine that the unrestricted importation of any plants, fruits. vegetables, roots, bulbs, seeds, or other plant products not included ly the term "nursery stock" as defined in section six of this act mas result in the entry into the United States ol' any of its Territories or District of injurious plant diseases or insect pests, he shall promulgate his deternination, specifying the class of plants and plant products the importation of which shall be restricted and the country and locality where they are grown, and thereafter, and until such promulgation is withlrawn. such plants and plant products imported or offered for import into the United States or "luy of its "Territories or Districts shall be mbject to all the provisions of the foregoing sections of this act: Provided, That before the Secretary of Agriculture shall promulgnte his determination that the unrestricted importation of any plants, fruits, vegetables, roots, bulbs, secols, or other plant products not inclumed by the term "nursery stock" as defined in section six of this act may result in the entry into the Uniter States or any of its Territories or Districts of injurious plant diseases or insect pests he shall, after due notice, give a public hearing, under such rules and regulations as he shall prescribe, at which hearing any interested party may appear and be heard, either in person or loy attorney.

SEc. 6. That for the purpose of this act the term "nursery stock" shall in(lute all field-grown florists' stock, trees, slumbs, vines, cuttings, grafts, scions, buds, fruit pits and other seeds of fruit and ornamental trees or shrubs, and other plants and plant prorlucts for propagation, except field, vegetable, and flower seeds, bedding plants, and other herbaccuns plants, bulbs, and roots.

SEc. 7. That whenever, in order to prevent the introduction into the United States of any tree, plant, or fruit disease or of any injurious insect, new to or not theretofore widely prevalent or distributed within and throughout the United States, the Secretary of Agriculture shall determine that it is necessary to forbid the importation into the United States of any class of nursery stock or of auy other class of plants, finits, vegetables, rots, bulls, seeds, or other plant products from a country or locality where such disease or insect infestation exists, le shall promulgate such determination, specifying the country and locality and the class of nursery stock or other class of plants, fruits, vegetables, roots, bulbs, seeds, or other plant products which, in his opinion, should be excluded. Following the promulgation of such determination by the Secretary of Agriculture, and until the withdrawal of the said promulgation by him, the importation of the class of nursery stock or of other class of plants, fruits, regetables, roots, Imlbs, seeds, or other plant products specified in the said promulgation from the country and locality therein named, regardless of the use for which the same is intended, is hereby prohibited; and until the withfrawal of the said promulgation by the Seretary of Agriculture, and notwithstanling that such class of nursery stock, or other class of plants, fruits. vegetables, routs, bullos, seeds, or other plant products be accompanied by a certificate of inspection from the country of importation, no person shall import or offer for entry into the United States from any country or locality specified in such promulgation, any of the class of nursery stock or of other class of plants, fruits, vegetables, roots, bulbs, seeds, or other plant products named therein, regardless of the use for which the same is intended: Provided, That before the secretary of Agriculture sliall promulgate his determination that it is necessary to forbid the importation into the Lnited states of the articles named in this section he shall, after due notice to interested parties, give a public hearing, under such rules and regulations as he shall prescribe, at which hearing any interested party may appear and be heard, either in person or by attorney: Provided further, That the quarantine provisions of this section, as aplying to the white-pine blister rust. potato wart, and the Mediterranean fruit fly, shall become and be effective upon the passage of this act: Provided further, That hereafter any class of nursery stock or of any other class of blants, fruits. vegetalies, roots, bulbs, seeds, or wher plant products of which the importation may be forbidden from any country or locality under the provisions of section seven of the Plant Quarantine Act approved August twentieth, nineteen hundred and twelve (Thirty-seventl Statutes, page flree hundred and fifteen), may be imported for experimental or scientific purposes by the Department of Agriculture upon sucli conditions and under such regulations as the said Secretary of Agriculture may prescribe.

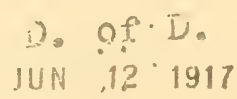


SEc. 8. That the Secretary of Agriculture is authorized and directen to quarantine any State, Territory, or District of the United States, or any portion thereof, when he shall determine that such quarantine is necessary to prevent the spread of a dangerous plant disease or insect infestation, new to or not theretofore widely prevalent or distributed within and throughout the United States; and the Secretary of Agriculture is clirected to give notice of the establishment of such quarantine to common carriers doing business in or through such quarantined aren, and shall publish in such newspapers in the quarantined area as he shall select notice of the establishment of quarantine. Thit no person shall ship or offer for shipment to any common carrier, nor shall any common carrier receive for transportation or transport, nor shall any person carry or transport from any quarantined State or Territory or District of the United States, or from any quarantined portion thereof, into or through any other State or 'Territory or District, any class of nursery stock or any other class of plants, fruits, vegetables, roots, bulbs, seeds, or other plant products, or any class of stone or quarry products, or any other article of any character whatsoever, capable of carrying any dangerous plant disease or insect infestation, specified in the notice of quarantine except as hereinafter provided. That it shall be unlawful to move, or allow to be moved, any class of mursery stock or any other class of plants, fruits, vegetables, roots, bulbs, seeds, or other plant products, or any class of stone or quarry products or any other article of any character whatsoever, capable of carrying any dangerous plant disease or insect infestation, specified in the notice of quarantine hereinbefore provided, and regardless of the use for which the same is intended, from any quarantined State or Territory or District of the United States or quarantined portion thereof, into or through any other State or Territory or District, in mamer or method or under conditions other than those prescribed by the Secretary of Agriculture. That it shall be the duty of the Secretary of Agriculture, when the public interests will permit, to make and promulgate rules and regulations which shall permit and govern the inspection, disinfection, certification, and method and manner of delivery and shipment of the class of nursery stock or of any other class of plants, fruits, vegetables, roots, bulbs, seeds, or other plant products, or any class of stone or quarry products, or any other article of any character whatsoever, capable of carrying any dangerous plant disease or insect infestation, specified in the notice of quarantine hereinbefore provided, and regardless of the use for which the same is intended, from a quarantined State or Territory or District of the United States, or quarantined portion thereof, into or through any other State or Territory or District; and the Secretary of Agriculture shall give notice of such rules and regulations as hereinbefore provided in this section for the notice of the establishment of quarantine: Prorided, That before the Secretary of Agriculture shall promulgate his determination that it is necessary to quarantine any State, Territory, or District of the United States, or portion thereof, under the authority given in this section, he shall, after due notice to interested parties, give a public learing under such rules and regulations as he shall prescribe, at which hearing any interested party may appear and be heard, either in person or by attorney.

SEc. 9. That the Secretary of Agriculture shall make and promulgate such rules and regulations as may be necessary for carrying out the purposes of this act.

SEc. 10. That any person who shall violate, any of the provisions of this act, or who shall forge, countelfeit, alter, deface, or destroy any certificate provided for in this act or in the regulations of the Secretary of Agriculture, shall be deemed guilty of a misdemeanor and shall, upon conviction thereot, be punished by a fine not exceeding $\$ 500 \mathrm{or}^{\circ}$ by imprisonment not exceeding one year, or both such fine and imprisonment, in the discretion of the court: Provided. That no common carrier shall be deemed to have violated the proxisions of any of the foregoing sections of this act on proof that such carrier did not knowingly receive for transportation or transport nursery stock or other plants or plant products as such from one State, Territory, or District of the United States into or through any other State, Territory, or District; and it shall be the cluty of the United States attorneys diligently to prosecute any violations of this act which are brought to their attention by the secretary of Agriculture or which come to their notice by other means.

SEc. 11. That the word "person" as used in this act shall be construed to import both the plural and the singular, as the case clemands, and shall include corporations, companies, societies, and associations. When construing and enforcing the provisions of this act, the act, omission, or fililure of any oflicer, 
agent, or other person acting for or employed by any corporation, company, society, or association, within the scope of his employment or office, shall in every case be also deemed to be the act, omission, or failure of such colporation, company, society, or association as well as that of the person.

SEc. 12. That for the purpose of carrying out the provisions of this act there shall be appointed by the Secretary of Agriculture from existing bureaus and offices in the Department of Agriculture, including the Bureau of Entomology, the Bureau of Plant Industry, and the Forest Service, a Federal Horticultural Board consisting of five members, of whom not more than two shall be appointed from any one bureau or office, and who shall serve without additional compensation.

SEC. 13. That there is hereby appropriated, out of the moneys in the Treasury not otherwise appropriated, to be expended as the Secretary of Agriculture may direct, for the purposes and objects of this act, the sum of $\$ 25,000$.

SEc. 14. That this act shall become and be effective from and after the first day of October, nineteen hundred and twelve, except as herein otherwise provided. 
Metal Edge, Inc. 2007 P.A.T. 
LIBRARY OF CONGRESS

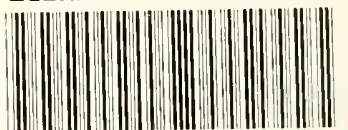

0 $020 \quad 973 \quad 1010$ 